\title{
Coda: 2018, Still struggling with a pair of shoes bought in 1996 ?
}

> S'nothile Gumede

Department of Visual Studies, Stellenbosch University, Stellenbosch, South Africa

snothile456@gmail.com (preferred pronouns: she/her)

\author{
For so long, \\ We have been suffering, violated and victimised, \\ For things, we cannot give name to, \\ All we knew was, \\ It's against our tradition.
}

Tradition and culture hold South African queers captive. South Africa, with perhaps one of the most progressive constitutions in the world is, in Gastrow's (1992) view, acknowledged for fostering ideas of democracy and equality across the continent. However, perhaps South Africa is not as free as it seems; perhaps, it is arguably only free because there is no alternative way to conceptualise the phase we are in as a country. It is questionable that marginal identities within the South African context are constantly subjected to violence and victimisation aggravated by how queerness is framed culturally and traditionally as taboo. Such stigmatisation of queer subjects is informed by hegemonic masculinity. Furthermore, queer visibility in the traditional landscape becomes a trap, as it is held as offensive to normative, traditional ways of being.

Gender, sexuality and identity in South Africa continue to be demarcated and defined under the parameters of tradition and culture (Morrell, Jewkes \& Lindegger 2012), which implies that any form of identity or orientation perceived as both deviant and subservient, such as queerness, is automatically stigmatised, tortured, violated and labelled as a taboo by heteronormative society (See De Ville 2010). An example, reflective of the torture and violence imposed on queer subjects in the name of culture and tradition, is the manner in which queer women are subjected to corrective rape 
and queer men experience death threats and discursive violence. The rejection and labelling of the LGBTQI+ community as a disgrace and taboo is increasingly becoming a quick-fix way of affirming heteronormative being, as well as going some way toward installing the integrity of culture and tradition as something sacred (Morrell, Jewkes \& Lindegger 2012). Thus, heteronormativity views on culture and tradition maintain the status quo by presenting the other as contaminated, as taboo.

The idea of presenting the other as contaminated, perverse and deviant resonates with Achille Mbembe's (2012:1) axiom: 'I alone possess value, but I can only be of value, as myself, if others, as themselves, are without value'.

Within such a framework, culture and tradition dismiss alternative, discursive horizons with the intention of binding society into a rigid system of heteronormative hegemony. See, for example, how the work of Zanele Muholi is critiqued for supposedly teaching society perverseness. Another example reflective of this shaming - the becomingtaboo - is the reaction of traditional groupings towards Inxeba and its effective banning from public display on grounds that it reveals and mocks a specific traditional act something that is purportedly meant to be (kept) sacred and secret. The larger question emerges from the clash between text and reception - why have cultural and traditional doctrines remained unquestioned or unexamined? Furthermore, if the film was internationally acknowledged yet rejected by its own people, to what extent should cultural and traditional ideological injunctions be held accountable?

Foucault's panopticon demonstrates the impact of mental captivity by such cultural and traditional ideological injunctions. The panopticon is the idea of an institutional building that is utilised to maintain power and order; in this institution, subjects are prisoned, isolated and constantly observed by an omniscient eye. The observed are conscious of this all-knowing and all-seeing eye, thus, they monitor their own behaviour, ensuring their behaviour correlates with set standards (De Ville 2010). In the context of Inxeba, queer subjects are caught in an unending web of gender performances, as they are conscious of the fact that traditional and cultural doctrines require them to do so. Additionally, various people around the queer subjects - all of whom are subject to these norms as well - carry out the enforcement of these doctrines. Xolani, for example, is afraid of openly expressing his unsanctioned sexual appetite because he is consciously aware that everyone in the initiation school unconsciously monitors people - and how his expression might lead to shaming and violation. This panopticism becomes internalised to such a degree that Xolani ignores his constitutional right of expressive identity - a right that was promulgated decades ago, in 1996. Rather, he falls subject to traditional and cultural norms owing to fear of being discursively 
ridiculed and emasculated by the traditionalist society for being a disgrace, or acting upon sexual impulses that are constructed as taboo.

How then do we reconcile culture, tradition and queerness? Are these mutually exclusive, as per the furore around the film's reception? Why is South Africa still struggling with liberty after twenty-odd years of freedom? These questions arguably bring into perspective the idea of challenging given norms that have no rational grounds, as they prevent our South African society from addressing gender and sexual identity problems. According to Karl Popper, '[t]he growth of knowledge proceeds from old problems to new problems by means of conjectures and refutations' (in Plotkin 2010:68). There exists the possibility of change, if attempts are made to question and destabilise regulatory systems that serve as stabilising labels of repressive systems, systems that were implemented under the twin banners of culture and tradition. Although various scholars and artists attempt to challenge regimes of gender, sexuality and identity as per culturally and traditionally socialised, it is arguably a difficult task as they are dealing with generational and information gaps that arise as a result of socialised discursive limits (set through this very same culture and tradition).

Against this, the Black Queer subject should sculpt alternative realities into existence, through literature, art and film without being labelled as perverse, deviant, or taboo. As a society, we need to learn to disturb the comfortable (those dwelling in the comfort that tradition and culture have to offer) and comfort the disturbed (those who are excluded and condemned in the name of culture and tradition).

\section{REFERENCES}

De Ville, J. 2010. Rethinking power and law: Foucault's society must be defended. International Journal for the Semiotics of Law 24(2):211-226.

Gastrow, S. 1992. Who's who in South African politics. Johannesburg: Ravan Press.

Mbembe, A. 2012. Metamorphic thought: the works of Franz Fanon. African Studies 71(1):19-28.

Morrell, R., Jewkes, R. \& Lindegger, G. 2012. Hegemonic masculinity/masculinities in South Africa. Men and Masculinities 15(1):11-3.

Plotkin, H. 2010. Evolutionary worlds without end. Oxford: Oxford University Press.

Yep, GA, Lovaas, KE, \& Elia, JP. 2003. Queer theory \& communication: from disciplining queers to queering the discipline. New York: Harrington Park Press. 